\title{
SUSCEPTIBILITY OF CANDIDA ALBICANS CLINICAL ISOLATES TO SOME PLANT EXTRACTS IN SAUDI ARABIA
}

\author{
Khalil Abdullah, Mohamed Soliman and Mohamed Mohamed.
}

Department of Medical Lab Science, Faculty of Applied Medical Science King Khalid University, Saudi Arabia.

\section{ABSTRACT}

The aim of this study is to determine the occurrence of Candida albicans in clinical specimens and studying its susceptibility to some plant extracts in Saudi Arabia.

One hundred twenty eight human clinical specimens from 98 cases suffering from oral thrush and 30 cases suffering from vulvovaginitis were examined by mycological examination. C. albicans was identified by standard methods. The susceptibility of C. albicans to nine medicinal plants extract (alcoholic) marketed in Saudi Arabia was examined.

The frequency of $\mathrm{C}$. albicans in the examined urine samples and oral swabs was 82.65 and $86.7 \%$, respectively. Zone of inhibition $(\mathrm{mm})$ of C. albicans against different plant extracts in different concentrations $(500-32000 \mu \mathrm{g} / \mathrm{ml})$ ranged from zero to $10 \pm 0.1$. The minimum inhibitory concentration ranged from 4000 to $32000 \mu \mathrm{g} / \mathrm{ml}$.

C. albicans is common in ICU cases either those with indwelling urinary catheter or those with oral thrush. The anticandidal activity of the examined plants extracts (alcoholic) may help in treatment and prevention of candidiasis.

Key words: Candida albicans, clinical, plant extracts, antimycotics, and sensitivity

\section{INTRODUCTION}

D ue to increased prevalence of drug resistant microorganisms there is great need to search for new effective drugs having natural or synthetic origin ${ }^{1}$. The resistance of pathogenic fungi, including C. albicans and non C. albicans species isolated from patient against anti fungal agents has increased ${ }^{2}$. Based on the toxicity and low potency, combined with the increasing side effects of these antimycotic drugs ${ }^{3}$, novel fungal therapies with fewer side effects on humans are urgently required for effective management of candidiasis infections ${ }^{4,5}$. Over the past decade, herbal medicine which has become a topic of augmented global importance has impacts on both world health and international trade. In terms of world health, traditional medicinal plants continue to play a center role in the health care system of large proportions of the world's population ${ }^{6}$. Recently, a number of researchers have reported the antimicrobial effects of various plant extracts against certain pathogens ${ }^{4}$. Medicinal plants have attracted considerable research attention as new sources of antimicrobial agents ${ }^{7,8}$. Wide varieties of plant extracts have antimicrobial and antimycotic effects and also anti-inflammatory properties ${ }^{9,10}$. There is a lack of available literature concerning the antimycotic effect of the marketed medicinal plants in Saudi Arabia. Candida species are members of the normal micro-biota with high prevalence in the normal population and can invade tissue and cause oral Candidiasis or life-threatening disease in patients whose immune defenses have been altered by old age, disease or iatrogenic intervention ${ }^{11}$. Possible risk factors causing an increase in Candida infections include prior antibiotic therapy, pregnancy, diabetes mellitus (DM), oral contraceptives containing estrogen and progestin, and immune-suppressed patients (transplanted patients, cancer patients treated with chemotherapy, and HIV patients) ${ }^{12}$. Vulvovaginal candidiasis (VVC) occurs at least once in $75 \%$ of women ${ }^{13}$. The aim of the present study was to assess the anti-candidal activities of nine plants extracts Acacia nilotica, Cardamom (Elettaria cardamomum), Datura stramonium, Dragon tree blood (Dracaena cinnabari Balf.f.), Ginger (Zingiber officinal), Neem (Azadirachta indica), Mangrove (Avicennia officinalis), Piperin (Piper nigrum) and Sedr (Zizphus spina-christi) against C. albicans isolated from human clinical cases.

MATERIAL AND METHODS

\section{Clinical specimens:}

The human clinical samples $(\mathrm{No}=128)$ including 98 urine samples and 30 oral thrush swabs were collected from ICU patients, King Faisal Hospital, Saudi Arabia during January-April, 2013. The examined cases age ranged from 40 to 70 years old including 98 female and 30 male. The specimens were transmitted within 4 hours to the laboratory of Microbiology, Faculty of Applied Medical Science, Bisha, King Khalid University for mycological examination. Each specimen was cultured on the surface of plates of Sabouraud dextrose agar (SDA) and incubated for 48 hours at $30^{\circ} \mathrm{C}$. The isolated yeasts were identified by: Gram's stain, Colonial morphology on SDA, small, creamy, smooth, moist, raised, and the yeasty odor were considered the suspected colonies of Candida species. Gram stained films of suspected colonies were examined microscopically. They revealed Gram positive ovoid shaped budding cells. Subculture of suspected colonies of Candida on SDA slopes for 48 hours at $30^{\circ} \mathrm{C}$ followed by storage at $4{ }^{\circ} \mathrm{C}$ to be used in further identification of colonies. All isolates proved to be Candida species by culture and microscopy were subjected to the following tests: Germ tube test, Chlamydospore production 
and Sucrose assimilation ${ }^{14}$. The local ethics committee approved this study, and all subjects gave informed consent to the procedures. The statistical analysis was done using the chi-square test ( $\mathrm{p} 0.05)$.

\section{Plant Materials}

Nine plant species were collected from Bisha market, Aseer, Saudi Arabia. The collected plants parts were air dried at room temperature, powdered and stored in dark colored bottles.

\section{Preparation of crude extracts.}

Two hundred and fifty grams of plant powder was soaked in 1.25-1.5 L of $95 \%$ ethanol for 5 days at room temperature, the mixture was mixed daily for regular infusion. After a five-day period, the extracted was filtered by using filter paper No1. The filtrate was dried by using a rotary evaporator at $60^{\circ} \mathrm{C}$. The dried extract was stored in sterile glass bottles at $-20^{\circ} \mathrm{C}$ until using ${ }^{15}$. The activity of the plant extracts was tested against $\mathrm{C}$. albicans, inoculums containing $10^{8}$ cells $\mathrm{ml}^{-1}$ were spread on the SDA. Antimicrobial activity test was then carried out by using the hole-plate diffusion method. Holes were made on the medium by using $6 \mathrm{~mm}$ cork borer. The dried plant extracts were dissolved in dimethylsulfoxide (DMSO) to final extract amounts of 500, 1000, 2000, 4000, 8000, 16000, $32000 \mu \mathrm{g} / \mathrm{ml}$. Each hole (diameter 6 $\mathrm{mm})$ in plate was filled with $50 \mu \mathrm{l}$ of plant extract $^{16}$.

The inoculated plates were incubated at $37^{\circ} \mathrm{C}$ for $24 \mathrm{~h}$. Zone to each hole was measured in millimeter, the inhibition zone is area surrounding the hole and there is no growth of inoculated microorganism. The lowest concentration of the plant extracts that didn't permit any visible growth of the incubated test organism in cultures was regarded as the MIC in each case ${ }^{17}$.

All assays were carries out in triplicates to calculate the mean results.

\section{RESULTS}

Table (1): Occurrence of C. albicans in the examined clinical cases.

\begin{tabular}{lllll}
\hline Source & No of cases & Positive & \multicolumn{2}{c}{ symptoms } \\
\cline { 2 - 5 } & & No. & Percentage & \\
\hline Urine samples & 98 & 81 & 82.65 & $\begin{array}{l}\text { Vulvovaginitis, fever, turbid urine or } \\
\text { sterile pyuria }\end{array}$ \\
\hline Oral swab & 30 & 26 & 86.7 & Oral thrush \\
\hline
\end{tabular}

Occurrence of C. albicans in the examined clinical samples was illustrated in Table 1. The obtained results showed that frequency of $\mathrm{C}$. albicans from urine samples and oral swabs were $82.65 \%$ and $86.7 \%$, respectively.

Table (2): Susceptibility of C. albicans to some plants extracts (alcohol) at different concentrations.

\begin{tabular}{|c|c|c|c|c|c|c|c|c|c|}
\hline \multirow[t]{2}{*}{ Plant name } & \multirow[t]{2}{*}{ Family } & \multirow[t]{2}{*}{$\begin{array}{l}\text { Plant } \\
\text { used }\end{array}$} & \multicolumn{7}{|c|}{$\begin{array}{l}\text { Zone of inhibition }(\mathrm{mm}) \pm \mathrm{SD} \text { at different concentrations of plant } \\
\text { extracts }\end{array}$} \\
\hline & & & $\begin{array}{l}500 \\
\mu \mathrm{g} / \mathrm{ml} \\
\end{array}$ & $\begin{array}{l}1000 \\
\mu \mathrm{g} / \mathrm{ml}\end{array}$ & $\begin{array}{l}2000 \\
\mu \mathrm{g} / \mathrm{ml}\end{array}$ & $\begin{array}{l}4000 \\
\mu \mathrm{g} / \mathrm{ml}\end{array}$ & $\begin{array}{l}8000 \\
\mu \mathrm{g} / \mathrm{ml}\end{array}$ & $\begin{array}{r}16000 \\
\mu \mathrm{g} / \mathrm{ml} \\
\end{array}$ & $\begin{array}{l}32000 \\
\mu \mathrm{g} / \mathrm{ml}\end{array}$ \\
\hline $\begin{array}{l}\text { Acacia } \\
\text { nilotica }\end{array}$ & Fabaceae & Leaves & 0 & 0 & 0 & 0 & 0 & $5.5 \pm 0.1$ & $8.5 \pm 0.1$ \\
\hline $\begin{array}{l}\text { Elettaria } \\
\text { cardamomum }\end{array}$ & Zingiberaceae & Seeds & 0 & 0 & 0 & 0 & $2.0 \pm 0.01$ & $6 \pm 0.2$ & $8 \pm 0.02$ \\
\hline $\begin{array}{l}\text { Datura } \\
\text { stramonium }\end{array}$ & Solanaceae & Leaves & 0 & 0 & 0 & 0 & $5 \pm 0.1$ & $7 \pm 0.1$ & $10 \pm 0.1$ \\
\hline $\begin{array}{l}\text { Dragon } \\
\text { Blood tree }\end{array}$ & Convallariaceae & Resin & 0 & 0 & 0 & 0 & $6 \pm 0.1$ & $8 \pm 0.1$ & $9 \pm 0.01$ \\
\hline $\begin{array}{l}\text { Ginger } \\
\text { (Zingiber } \\
\text { officinale) } \\
\end{array}$ & Zingiberaceae & Rhizomes & 0 & 0 & 0 & 0 & 0 & $7 \pm 0.2$ & $10 \pm 0.1$ \\
\hline $\begin{array}{l}\text { Neem } \\
\text { (Azadirachta } \\
\text { indica) }\end{array}$ & Meliaceae & Leaves & 0 & 0 & 0 & $5 \pm 0.1$ & $7 \pm 0.1$ & $8 \pm 0.1$ & $10 \pm 0.1$ \\
\hline Mangrove & Rhizophoraceae & Leaves & 0 & 0 & 0 & $2 \pm 0.2$ & $6 \pm 0.2$ & $7 \pm 0.1$ & $10 \pm 0.1$ \\
\hline Black pepper & Piperaceae & Seed & 0 & 0 & 0 & $2 \pm 0.2$ & $5 \pm 0.2$ & $8 \pm 0.1$ & $10 \pm 0.1$ \\
\hline $\begin{array}{l}\text { Zizyphus } \\
\text { (Sedr) }\end{array}$ & Rhamnaceae & Leaves & 0 & 0 & 0 & 0 & $6 \pm 0.1$ & $7 \pm 0.1$ & $9 \pm 0.01$ \\
\hline
\end{tabular}

$\mathrm{SD}=$ Standard deviation 
The plant extract that used in this study experiment were Acacia nilotica, Cardamom (Elettaria cardamomum), Datura stramonium, Dragon tree blood (Dracaena cinnabari Balf.f.), Ginger (Zingiber officinal), Neem (Azadirachta indica), Mangrove (Avicennia officinalis), Piperin (Piper nigrum) and Sedr (Zizphus spina-christi) against the reference strain of C. albicans. Data presente in Table 2 indicate that the alcoholic extracts of the tested plants extracts had inhibitoty effect against C. albicans. The inhibitory rate differe according to plant used. The zone of inhibition of the tested strains was zero for all plants extract at concentrations 500, 1000 and $2000 \mu \mathrm{g} / \mathrm{ml}$. The zone of inhibition (range by $\mathrm{mm}$ ) at concentration of 4000,8000, 1600 and 3200 $\mu \mathrm{g} / \mathrm{ml}$ were $0-5 \pm 0.1,0-7 \pm 0.1,5-8 \pm 0.1$ and 8 $10 \pm 0.1$, respectively. The obtained results indicated that Neem alcoholic extract had the most antifungal activities against the tested strains. The lowest antifungal action against $\mathrm{C}$. albicans was Acacia nilotica.

\section{DISCUSSION}

Recently, the occurrence of C. albicans has greatly increased with the introduction of broadspectrum antibiotics, immunosuppressive corticosteroids and prolonged antibacterial therapy. Among species of the genus Candida, C. albicans is the prevalent causative agent of candidiasis and constitutes the fourth most common nosocomial bloodstream isolate in industrial countrie ${ }^{11}$. In the present study (Table $1)$, the frequency of $\mathrm{C}$. albicans in oral swabs were higher than that recorded previously $(49.3 \%)$ by ${ }^{18}$. The variation in frequency of $\mathrm{C}$. albicans may be due to stress. The high incidence of $\mathrm{C}$. albicans among such human cases confirms the opportunistic nature of that organism which always taking advantages of stress factors or other disease conditions in the host ${ }^{19}$. The frequency of carriage of candidal colonization increased as a function of age $\mathrm{e}^{20}$. A similar result was found previously by El-Sayed and Hamouda ${ }^{21}$ who isolated C. albicans from vulvovaginitis cases with the percentage of $86.6 \%$. Moreover, C. albicans was previously isolated from vaginitis cases with the frequencies of $67 \%, 84.9 \%$, and $73 \%$ by Richter et al. ${ }^{22}$, DeVos et al. ${ }^{13}$ and Pirotta and Garland ${ }^{23}$, respectively.

Plant extracts and their products are clinically safer than antibiotic ${ }^{24}$. Nowadays, the natural products and medicinal plants are subject of great global interest for the discovery of new antimicrobial agents ${ }^{25}$. This could be related to the recent failure of antibiotics against the dramatic emerging of multidrug resistant pathogens in addition to the rapid spread of the new infections $^{26}$. There is no available literature discussing the sensitivity of C. albicans against the tested plants extract in Saudi Arabia. Previous studies found that the ethanolic extracts of some Italian and Ethiopian plants have antimycotic activities against $\mathrm{C}$. albicans. Further studies are needed to study the effect of combination of plants extracts as anti-candidal activities. ${ }^{28,27}$

The obtained results indicate that Neem (Azadirachta indica), Mangrove and Piper nigrum was very active against $C$. albicans. It inhibited the Candida growth at the four extract amounts $(4000,8000,16000$ and $32000 \mu \mathrm{g} / \mathrm{ml}$. It had a minimum inhibitory concentration (MIC) of 4000 $\mu \mathrm{g} / \mathrm{ml}$ and gave inhibition zone of $5.0 \pm 0.1$, $2.0 \pm 0.2$ and $2.0 \pm 0.2$, respectively. Zizyphus (sedr), Dragon blood tree and Eletaria cardamomum also were active against $\mathrm{C}$. albicans. It inhibited the Candida growth at three extract amounts $(8000,16000$ and $32000 \mu \mathrm{g} / \mathrm{ml}$. It had a minimum inhibitory concentration (MIC) of $8000 \mu \mathrm{g} / \mathrm{ml}$ and gave mean inhibition zone of $6.0 \pm 0.1, \quad 6.0 \pm 0.1$ and $5.0 \pm 0.1$, respectively. Ginger and Acacia nitolica seem less active against C. albicans. It inhibited the Candida growth at the two extract amounts (16000 and $32000 \mu \mathrm{g} / \mathrm{ml}$ ). It had a minimum inhibitory concentration (MIC) of $16000 \mu \mathrm{g} / \mathrm{ml}$ and gave inhibition zone of $7.0 . \pm 0.2$ and $5.5 \pm 0.1$ respectively (Table 2 ).

Hassawi and Kharma ${ }^{29}$ worked on C. albicans. It was resistant to the extract of Convolvulus althaeoides and it was affected by extract of Convolvulus arvensis at extract amounts (200 and $150 \mathrm{mg} / \mathrm{ml})$. This could be due to genetic variations between two species or higher concentrations of extract need to be used. Present results indicated that the tested plant extracts could have an anti-C. albicans effect. The active agent that caused the antimycotic activity of these medicinal plants against $C$. albicans need further studies to study the pharmacological action of it. Also, these plants extract may have the same agent but in different concentrations that causes high variations in their antimicrobial activity.

It could be concluded from the present study that candidiasis is a common nosocomial organism in ICU especially in those with indwelling urinary catheter and oral thrush in the current study. The tested plants extract having an antimycotic activity with various potencies and could be used for alternative medicine for treatment of candidiasis.

\section{ACKNOWLEDGEMENTS}

Indebted thanks to Dr. Magdy Mohamed, Department of Internal Medicine, King Faisal 
Hospital, Taif, Ministry of Health, Saudi Arabia REFERENCES

1- Pai MR, Acharya LD, Varun N (2004): Evaluation of antiplaque activity of Azadiachta Indica leaf extract get a 6 week clinical study. Journal of Enthnopharmacology 90: 99-103.

2- Citak S, Ozcelik B, Cesur S, Abbasoglu U, (2005).In vitro susceptibility of Candida species isolated from blood culture to some antifungal agents Japanese Journal of Infectious Diseases;58:44-46.

3- Devkatte AN, Zore GB, Karuppayil SM, (2005). Potential of plant oil as inhibitors of Candida albicans growth. FEMS Yeast Research; 5:867-873.

4- Papadopoulou C, Soulti K, Roussis IG, (2005). Potential antimicrobial activity of red and white wine phenolic extracts against strains of Staphylococcus aurous, Escherichia coli and Candida albicans. Food Technology and Biotechnology;43:41-46.

5- Seneviratne CJ, Wong RWK, Samaranajake LP, (2008). Potent anti-microbial activity of traditional Chinese medicine herbs against Candida species .Mycoses; 51:30-34.

6- Akerele O. (1988). Medicinal plants and primary health care: an agenda for action. Fitoterapia;59:355-363.

7- Pawar VC, Thaker VS, (2006). In vitro efficacy of 75 essential oils against Aspergillus niger.Mycoses;49:316-323.

8- Taweechaisupapong S, Choopan T,Singhara S, Chatrachaiwiwantana S, Wongkham S, (2005). In vitro inhibitory effect of Streblus asper leaf extract on adhesion of Candida albicans to human buccal epithelial cells. Journal of Ethnopharmacology; 96:221-226.

9- Chaieb K, Zmantar T, Ksouri R, et al., (2007). Antioxidant properties of the essential oil of Eugenia caryophyllata and its antifungal activity against a large number of clinical Candida species. Mycoses; 50:403-406.

10- Saikia D, Khanuja Sps, Kahol AP, Gupta SC, Kumar S, (2001). Comparative antifungal activity of essential oils and constituents from three distinct genotypes of Cymbopogon spp. Current Science;80:1264-1266.

11- Reimer LG, Wilson ML, Weinstein MP, (1997). Update on detection of bacteremia and fungemia. Clin Microbiol Rev; 10: 444-65.

12- Lanchares, J. L. and Hernandez, M. L. (2000). Recurrent vaginal candidiasis changes in etiopathogenical patterns. Int. J. Gynecol. Obstet. 71: S29-S35.

13- De Vos M., M. Estrella C., Boekhout T., Theelen B., Matthijs N., Bauters T., Nailis H., Dhont M.(2005). Vulvovaginal candidiasis in a Flemish patient population J. Clin. Microbiol. and Infec, 11 :NO 12, p1005-1011

14- Forbes B.A., Sahm D.F. and Weissfeld A.S. (1998). Laboratory methods in basic for clinical samples collection.

mycology. In Bailey and Scott's Diagnostic Microbiology $10^{\text {th }}$ ed. Mosby. St. Louis Mo p. 871-958.

15- Kandil, O., N.M. Radwan, A.B. Hassan, A.M.M. Amer,H.A. El-banna and W.M.M. Amer, (1994). Extracts and fractions of Thymus capitatus exhibit antimicrobial activities.J.Ethnapharmacol., 45:97-111.

16- Ebi GC, (1997). Ofoefule SI.Investigation into the folkoric antimicrobial activities of Landolphia owerriance. Phytother Res;11:147151.

17- Ressel, A.D and Furr, J.R, (1977). Antibacterial activity of new chloroxlenol preparation containing ethylene diamine tetracetic acid.J.AppI.Bacterial,43:253-260.

18-Zaremba ML, Daniluk T, Rozkiewicz D, Cylwik-Rokicka D, Kierklo A, Tokajuk G, et al., (2006). Incidence rate of Candida species in the oral cavity of middle-aged and elderly subjects. Advances in Medical Sciences 51(Suppl 1):233-136.

19- Domart, Y.; Delmas, V.; Cornud, F.; Bouchama, A.; Chastre, J.and Gibert, C. (1986). Urinary tract obstruction by fungus balls. Presse Med., 15 (4) 153-156.

20- Lockhart, S.R., Joly S., Vrgas, K., SwailsWeger J., Enger L. and Soll D.R. (1999). Natural defense against Candida colonization breakdown in the oral cavities of the elderly. $\mathrm{J}$ Dent Reas, 78; 857-68.

21- El-Sayed, H. and Hamouda, A. (2007). Candida albicans causing vulvovaginitis and their clinical response to antifungal therapy. Egyptian Journal of Medical Microbiology, 16(1):53-62.

22- Richter S. , R. P. Galask, S. A. Messer, R. J. Hollis, D.J. Diekema, and M. A. Pfaller (2005). Antifungal Susceptibilities of Candida Species Causing Vulvovaginitis and Epidemiology of Recurrent Cases. J Clin Microbiol. 43(5): 2155-2162.

23- Pirotta M. V. and Garland S. M. (2006). Genital Candida Species Detected in Samples from Women in Melbourne, Australia, before and after Treatment with Antibiotics. J Clin Microbiol 44(9): 3213-3217.

24- Kelmanson JE, and Staden JZ (2000). Medicinal plants with antimicrobial activity. Journal of Ethnopharmacol 69: 241-246.

25- Sashikala GD, Kottai AM, Satheesh DK, Rekha S, Indhumathy, Nanhini R. (2009). Studies on the antibacterial and antifungal activity of ethanolic extract of Luffa cylindrica (Linn) Fruit.Int. J. Drug Dev.Res.,1(1):105109.

26- Abdallah E, M. (2011).Plants: An alternative sources for antimicrobial.J.Applied Pharma.SCI.,1(6):16-20.

27- Colin, M.E.; Doucos de Lahitte, E.Larribau and T, Boue.(1989). Activite de huiles 
essentielles de Labiees Sur As Cosphaera Apis et Treatment dune Rucher. Apidologie 20, 221-228.

28- Desta, B. (1993). Ethiopian traditional herbal drugs. Part II, Antimicrobial activity of 63 medicinal plants" Journal

Ethnopharamacology 39 (2): 129-139.

29- Hassawi D. and Kharma A. (2006). Antimicrobial activity of some medicinal plants against Candida albicans.Journal of Biological Sciences 6(1):109-114. 
حساسية العزلات الإكلينيكية للكانديدا المبيضة لبعض المستخلصات النباتية بالمملكة العربية السعودية

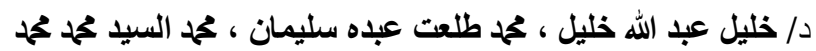

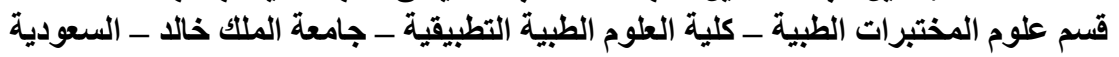

تهدف الدراسة الحالية تحديد تواجد الكانديدا المبيضة في العينات الإكلينيكية لمرضى التهاب المهيل الثفري وسُلاًق الفم وكذلك در اسة حساسيتها لبعض المستخلصات النباتية بالسعودية.

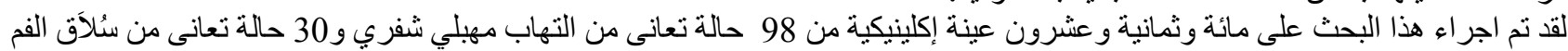

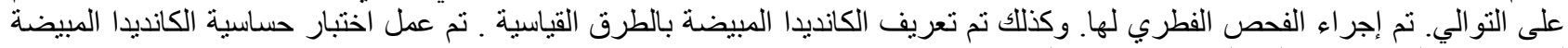
لعدد 9 مستخلصات (كحولية) لنباتات مسوقة النئة بالسعودية.

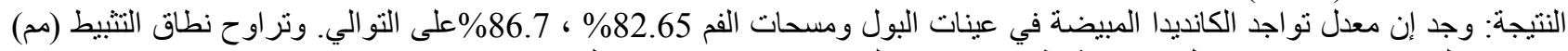

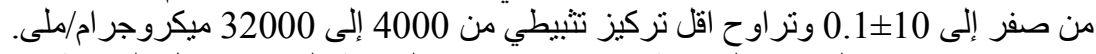

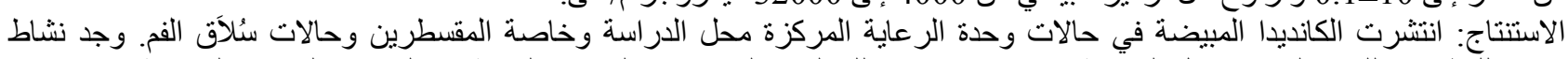

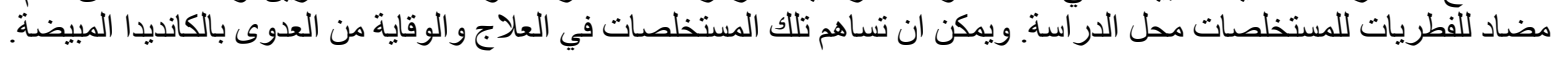

